\title{
TOWARDS A MULTIDISCIPLINARY APPROACH IN CREATIVE SUBTITLING
}

\author{
Rebecca McClarty \\ Queen's University Belfast (United Kingdom) \\ rmcclarty01@qub.ac.uk
}

\begin{abstract}
Standard subtitling practices have long been influenced, if not governed, by norms and conventions such as the Code of Good Subtitling Practice (Ivarsson \& Carroll 1998). Yet recent research into film subtitling has begun to take a creative turn: a trend that is matched by increasing numbers of fansubs and professionally produced creative subtitles. This paper seeks to demonstrate the need for a multidisciplinary approach to creative subtitling and, by drawing upon principles from film studies, suggests some key features for the development of a creative subtitling practice.
\end{abstract}

\section{Resumen}

Hace mucho tiempo que las normas y convenciones del subtitulado, como las del Code of Good Subtitling Practice (Ivarsson \& Carroll 1998), influyen y regulan la práctica estándar del subtitulado. No obstante, las investigaciones recientes sobre el subtitulado cinematográfico han empezado a tratar el tema del subtitulado creativo: una tendencia que se corresponde con el número cada vez mayor de fansubs y también con el empleo de subtítulos creativos en varias películas profesionales. En este trabajo se pretende demostrar la necesidad de desarrollar un enfoque multidisciplinario del subtitulado creativo y, mediante varias aportaciones de los estudios cinematográficos, sugiere algunas características clave para el desarrollo de una práctica de subtitulado creativo.

Keywords: Creative subtitling. Aesthetics. Multidisciplinarity. Film studies. Audiovisual translation.

Palabras clave: Subtitulado creativo. Estética. Multidisciplinariedad. Estudios cinematográficos. Traducción audiovisual. 
Manuscript received on June 24, 2011; Definitely accepted on November 15, 2011. 


\section{Introduction}

Standard subtitling practices have long been governed by the constraints of the field and the norms designed to respond to these constraints. Indeed, the initial label of "constrained translation" (Titford 1982; Mayoral et al. 1998) applied to the field of audiovisual translation (AVT) highlights academics' preoccupation with these constraints. As a response to the constraints of subtitling, and in search of a set of rules to govern the quality of subtitle production, norms and conventions such as the Code of Good Subtitling Practice (Ivarsson \& Carroll 1998) and Karamitroglou's A Proposed Set of Subtitling Standards in Europe (1998), among others, were developed, and these remain the founding statements for the didactics of subtitling. Despite the fact that television channels and subtitling companies have adapted these norms for their own requirements and in spite of the increased awareness of the need to develop subtitling practices along with new technologies, subtitling practitioners continue to have their hands tied by the constraints of the field and the norms of the profession. By remaining focused on these norms, subtitlers have largely failed to acknowledge the insights that could be gained by referring to audiovisual translation's parallel discipline: film studies. While translators of poetry become poets, and translators of plays become playwrights, by failing to acknowledge the importance of film studies, film translators have largely been reduced to mere norm-obeying machines. This trend may, however, be set to change with the new interest that has been given to creative or aesthetic subtitling practices.

In this article, I will examine the origins and implications of this new creative turn in subtitling, before considering the need for a multidisciplinary, film studies-based approach. I will then suggest several specific elements of film studies that can be applied to a creative subtitling practice, before reflecting upon the effects of such an approach, both on the communicative functions of subtitles and on the specific role of the subtitler. 


\section{From Past to Present in Creative Subtitling}

In contrast with the restrictions imposed by subtitling norms, recent research has returned to the possibility of creativity in subtitling. To say "returned" here is to consider the origins of current subtitling practices. Nornes (2007: 103), for example, has drawn attention to the artistry involved in the design of intertitles during cinema's silent era. The designers of these intertitles adopted an approach similar to that of a graphic designer, using curved lines of text, decorative borders and simple animations. Indeed, at the beginning of the twentieth century there was certain optimism for what could be achieved through intertitles:

At first they were pleasingly decorative; later they aided in interpreting the mood of the play. The text of the subtitles not only advanced the story, but when conversation was used, helped the characterization; and the skilful word pictures aided and completed the scene. (Harris 1916; quoted in Bordwell, Staiger \& Thompson 1985: 187)

While the creation of intertitles at that moment in history was of huge significance for the development of cinematic narrative, Harris' approval of the "skilful word pictures" demonstrates an early appreciation of the potential creative function of intertitles. It also highlights the capacity of creative subtitles to advance characterisation and "[complete] the scene". This early optimism, however, was to be short lived as the increasing commercialisation of the film industry meant that reproducing creative intertitles in different languages became too expensive. By the early twenties, then, the translation of films was already on the road to becoming the normalised, cost-conscious process that is in place today.

While Nornes (1999: 25-28) makes reference to the use of creative linguistic and graphic subtitling styles in Japan from the thirties to the present day, subtitling styles in the Western world have changed little over the past eighty years. Without wishing to digress into a discussion of the merits or shortcomings of current subtitling norms, it suffices to say that these conventions, which form the basis for quality control and the didactics of subtitling, have now become a powerhouse that is difficult to escape. Yet an indication of the insufficiency of these norms can be found in the increasing number of amateur fansubs and the adoption of some fansubbing techniques by commercial DVD distributors [for example, Caffrey (2009) has drawn attention to the use of 'abusive' subtitling strategies on the DVD release of Paniponi Dash! Lethal Lesson (Onuma, 2007), distributed by ADV films]. Fansubs, which were initially produced by anime fans and are now developed for a wide range of audiovisual media, can be seen as a response to the failure of anime distributors to 
fulfil the specific demands of that fan community. Faced with the plain styles and domesticating translations of standard subtitling practices, fansubbers have developed an approach that uses various fonts, colours and positions along with notes and glosses in the translation (Ferrer Simó 2005: 29-30). The rapid growth in popularity of fansubbing practices has since forced the hand of anime distributors, leading them to adapt their subtitling styles and include additional features such as pop-up glosses. Indeed, as Díaz Cintas (2005) has pointed out, the greater flexibility afforded by new technologies (and in particular the home entertainment market) has given rise to a shift in subtitling styles. These changes relate to dialogue techniques, the number of lines per subtitle, the use of colours, cumulative subtitles and metatextual information (ibid.). Nevertheless, these small changes to standard subtitling practices do not truly represent a paradigm shift in the subtitling process. Indeed, they are still arguably less creative than the first intertitles produced almost a century ago.

This frustration is evidenced in Nornes' (1999) tirade on "corrupt" subtitling practices. Nornes disavows standard subtitling practices because of their misjudged insistence on invisibility, their domesticating translation strategies and the violence they exert on the source text. This fraudulent approach, he argues, pretends to move the target audience closer to the foreign, while in fact imposing the target culture upon the source culture. The alternative, then, is to adopt an "abusive" subtitling strategy by performing an abuse on the target culture (ibid.: 28). This may take the form of a linguistic or graphic abuse: for example, the use of "[untranslatable French pun]" where there is no adequate translation, or subtitles growing in size to graphically represent the shouted dialogue of a character (ibid.: 25).

More recently, Nornes' concepts have been used as the basis for a 'new' form of creative or "aesthetic" subtitling (Foerster 2010: 85). In Foerster's recent case study of the creative subtitles used in the cinematic release of the Russian film Night Watch (Berkmambetov 2004), Foerster upholds Nornes' observation of the impossibility of invisibility in subtitling, and analyses the style and efficacy of the innovative subtitles, making particular reference to the Code of Good Subtitling Practice (1998). These subtitles occasionally appear in different positions or with different fonts and colours; at times characters can step in front of them, and at other times they become distorted along with the mise en scène. Foerster proposes the need for greater innovations in subtitling and, in particular, creative subtitling, and stresses the need for subtitles to become tailored to individual films. However, she ultimately concludes that, despite many positive qualities, the subtitles do not "meet 
all the criteria necessary to be regarded as satisfactory by experts" (Foerster 2010: 95). Yet perhaps no other conclusion can be reached if creative subtitles are only judged against the standardised norms of the Code of Good Subtitling Practice. These are the conventions that have, ultimately, formed the basis for standard "corrupt" subtitling practices. How, then, can aesthetic subtitles that have been produced according to the terms of the Code ever be truly creative or "abusive"? Regardless of how timely, beneficial or aesthetically pleasing a creative subtitling strategy may be, referring only to ideas from within translation studies and audiovisual translation will fail to produce a new form of subtitling that is truly innovative. It is for this reason that AVT academics and practitioners must develop a multidisciplinary approach, reaching out to other disciplines as in the first days of intertitles, to form a subtitling strategy based on principles from film studies, graphic design and beyond.

\section{Multidisciplinarity in Creative Subtitling}

Further recent research in AVT has begun to turn towards a multidisciplinary approach. Chaume (2004), in particular, has proposed a film studies-based approach for the analysis of audiovisual texts. By identifying ten "signifying codes of cinematic language" (ibid.: 16) relating to the cinema's acoustic and visual channels, he has drawn attention to the large number of semiotic codes in the film text. Indeed, only one of his ten codes relates to linguistic issues, and even within this code, Chaume is quick to point out that translational difficulties, such as wordplay and culture-specific objects, are not unique to audiovisual texts (ibid.:17). It is, in fact, the shift from written script to 'prefabricated orality' that poses the greatest linguistic difficulties for the film translator. This emphasis on the multiple acoustic and visual "signifying codes" that make up each and every audiovisual text could, then, be seen as a convincing argument for the implementation of a creative subtitling practice. By focusing for so long on the linguistic code, AVT scholars have failed to address the requirements posed by the numerous other layers of meaning in film texts. Therefore, by developing a truly multidisciplinary approach to audiovisual translation, a creative subtitling strategy can fully respond to the communicative needs of each and every film text.

In developing a responsive, creative subtitling strategy, it may prove fruitful to draw upon other areas of translation where such an approach has already been adopted. The recent practical turn in theatre translation is one such example. Theatre translators have now come to realise that performability must be tailored to and contingent upon the specific aesthetic qualities of the individual play that is being translated. This dawning realisation is 
strongly linked to a clear awareness of the importance of multidisciplinarity in theatre translation:

At the most general level, how we consider and think about translation for performance has more to do with theatre practice than it has with translation theory strictu sensu. That is not to deny the clear and potentially very fruitful relationship between theory and practice, but to subordinate performanceled practice to a hierarchy of theory [...] effectively serves to decontextualise practice from the imperatives that drive it. (Johnston 2010: 15)

Multidisciplinarity, then, and in particular cross-disciplinary collaboration, is at the heart of this practical turn. Johnston goes on to note that this collaboration between theatre translators, directors and actors may, at its best, create a "meaningful" experience in the mind of the spectator. Translation, he argues, is:

$[\ldots]$ a process that $[\ldots]$ engineers two-way movement - a traffic between the narratives, concepts and structures of life embodied in foreign texts, and the affective and cognitive environment of the spectator. (ibid.: 21)

Does this not resonate with Nornes' suggestion that "abusive" subtitles should provide the spectator with an "experience of translation" (1999: 18)? The term "abusive", however, is perhaps somewhat misplaced, implying a oneway traffic from the source text to the target audience. Creative subtitling is a more appropriate and much less charged term, yet it must be used with some caution: not simply to describe a subtitling practice that differs from the norm, but to denote an approach that looks outward from its own discipline as well as its own culture. In short, film translation, like theatre translation, must become a creative practice. Standard subtitling conventions, by restricting subtitlers to a generic set of norms, convert the translator into a mere ruleobeying machine rather than the creative collaborator that can be found in the figure of the theatre translator. The creative subtitler, therefore, must keep a trilateral gaze: backwards to the source culture and the aesthetic qualities and semiotic codes of the source text; sideways to the influences to be gained from related disciplines; and forwards to the target culture and the aesthetic qualities and semiotic codes of the subtitles.

It therefore follows that subtitles should respond to each specific film as other forms of translation respond to their respective specific text types - and not simply in terms of constraints. Standard subtitling practice, as it is now and as it has been for the largest part of its history, is often defined negatively by its constraints. In contrast, the creative subtitling practice allows a more positive view of the qualities (not constraints) of this form of translation. Rather than adhering to a restrictive set of norms, the creative subtitling 
practice responds to the specific qualities of the individual film text, giving the creative subtitler more freedom to create an aesthetic that matches that of the source text, instead of being bound by standard font types, sizes and positions. Creative subtitles may be subtle or striking, bright or neutral, wild or restrained, but they will always respond to the individual film text, or even to specific moments within that film text. This change in convention means that creative subtitles will never be "invisible" (if, indeed, subtitles have ever been "invisible"). Yet the aim of creative subtitles is not to "invisibly" reproduce the same effect on the target audience as that of the source audience. For who is to say what that experience is? Who is to say that that experience can be defined as one single unifying experience? Creative subtitles, then, aim to achieve difference rather than sameness. Just as other texts are completed in translation, given new meaning as they move across cultures, so too will creative subtitles allow the film text to gain new meanings in translation.

As we have seen, it is the multidisciplinary nature of creative subtitles that allows them to become truly creative. While Chaume (2004) has gone some way towards multidisciplinarity by analysing the signifying codes of the audiovisual text, further research must be carried out in order to develop a multidisciplinary subtitling practice. In the next section, we will examine key principles from film studies in a bid to develop this creative subtitling practice.

\section{New Insights from Film Studies and Beyond}

As a starting point, it may be useful to observe previous instances of graphically creative subtitles. We have already seen that creative subtitles are, in themselves, no new idea. The use of graphic design methods by intertitle writers (including Hitchcock himself) during the silent era and the adoption of innovative graphic methods by Japanese subtitlers in the thirties is testament to this very fact. While such creative subtitling methods have remained largely unused in the West over the past number of decades, more and more filmmakers are utilising new advances in digital film editing software to produce more innovative results in subtitling. These subtitles (which, it must be pointed out, are the products of the imagination of film directors and editors rather than subtitlers) are often used to produce a certain narrative or comedic effect, or to interact with the film's soundscape and mise en scène. A first example of this type of subtitle usage can be found in Jay Roach's popular Hollywood genre film Austin Powers in Goldmember (2002). In this case, the subtitles are used for comedic effect (see Figure 1). 

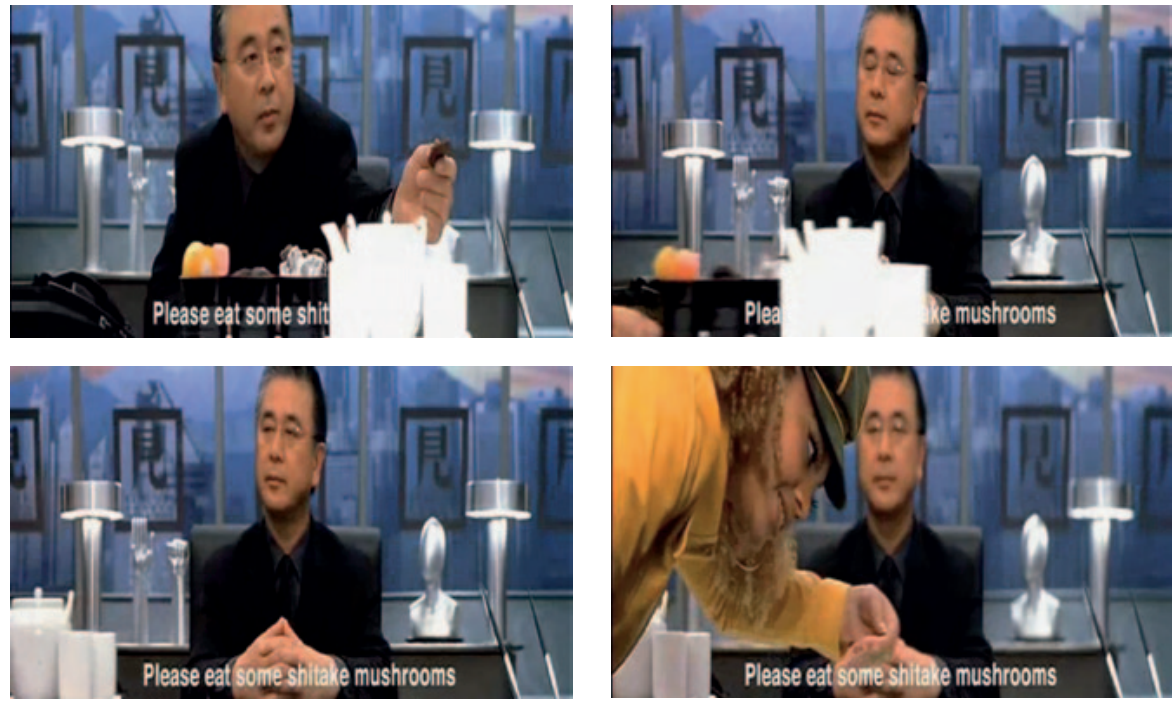

Figure 1: Subtitles for comedic effect in Austin Powers in Goldmember.

This subtitling technique is used several times in a scene between Austin Powers, his colleague Foxxy Cleopatra and a Japanese businessman, Mr Roboto. On each occasion, both Powers and Cleopatra are able to read the subtitles along with the viewers: a technique that is rather fitting for this film, since Powers often breaks the illusion of the reality of film by speaking directly to the audience. The subtitles, in fact, become part of the mise en scène itself, with actual objects sitting in front of them, obscuring their view from the characters as well as the audience.

Another example of film editing techniques used for subtitle production can be found in the Argentinean art film, La antena (Sapir, 2007). This black and white film harks back to films of the silent era, with neo-noir and expressionist styles. The film is set in an imagined city in the year XX, the inhabitants of which have lost their voices. Motion typography is therefore used to represent the characters' dialogue (see Figure 2).

Rather than being used for comedic effect as in the first example, these 'subtitles' perform both a narrative and an artistic function. Once again and, indeed, to an even greater extent, these 'subtitles' are fully integrated into the mise en scène, providing a vehicle for understanding for both the characters and the audience. Clearly the film was always intended to be read with subtitles, even by its native audience, and was therefore filmed and edited in such 

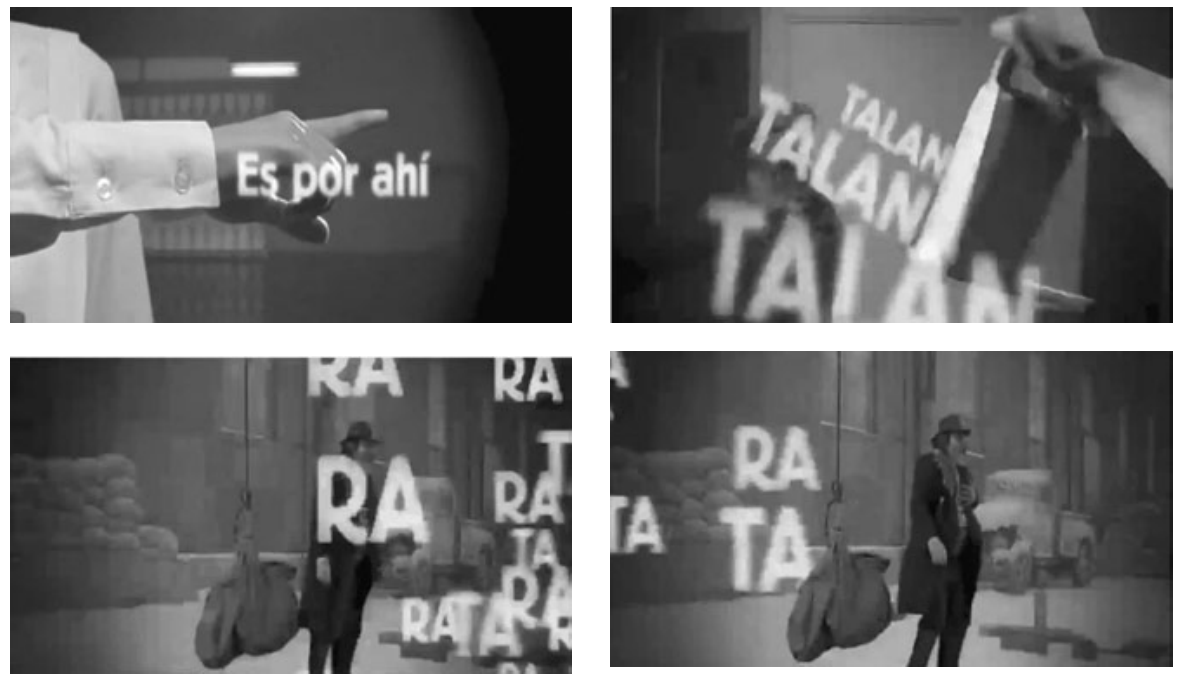

Figure 2: Motion typography in La antena

a way that the subtitles could be integrated into the mise en scène without very great difficulty. Interlingual subtitlers, of course, do not usually have this luxury. Nevertheless, the motion typography used in La antena shows the levels of artistic merit that can be achieved through subtitles that fully blend with and respond to their backdrop.

As a final example of recent creative uses of subtitling, we will examine Danny Boyle's multi Academy Award winning film, Slumdog Millionaire (2008). Subtitles are provided for a third of the film's dialogue, and, in particular, for the flashbacks to the protagonist's childhood (see Figure 3).

The primary function of these subtitles, unlike those used in the previous examples, is translation. Yet their linguistic function has not impinged totally upon their graphic style. The subtitles are always set against a semi-transparent
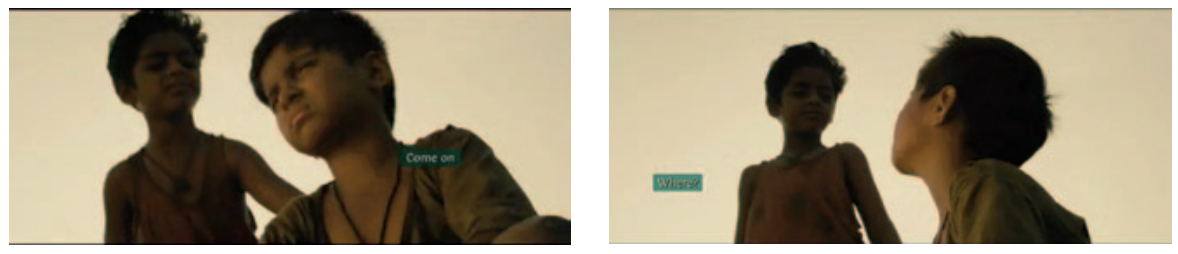

Figure 3: Creative subtitles in Slumdog Millionaire. 
box to ensure their visibility, but, contrary to standard subtitling conventions, the colour of the transparent box changes according to the colour scheme of the mise en scène. What is even more striking, however, is the change in position of the subtitles. Rather than remaining at the bottom of the screen, as is standard subtitling practice, the subtitles have been raised to a more prominent position within the action of the film. They also jump from one side of the screen to the other, seemingly attempting to follow the flow of dialogue between characters. Indeed, the positioning of the subtitles, on the whole, works to keep the audience engaged with the plight of the two young boys. By commissioning this style of subtitles, Boyle has put faith in his viewers and refused to underestimate them. Although there are legibility issues with some of the subtitles, the point of the subtitles in this film seems to be that the audience gains an overall understanding of the situation and dialogue, rather than a word by word comprehension of each subtitle. This is further evidenced through the sparse use of subtitles: repeated utterances, for example, are not given a second subtitle, nor are subtitles provided for emphatic words or unessential background dialogue. Boyle has therefore achieved a set of subtitles that fulfil their linguistic, translational function, while also fulfilling an equally important aesthetic function through their colour and an affective function through their positioning in the heart of the on-screen action.

Rather significantly, as previously mentioned, these creative subtitles, with all their comedic, narrative and artistic functions, stem from the creative mind of the filmmaker; not the linguistic mind of the translator. Indeed, professional subtitlers and AVT academics have freely admitted the creative limitations of their 'art': "For many cinema professionals and film buffs subtitles are a blemish on the film screen and we do not really wish to contradict them" (Díaz Cintas \& Remael 2007: 82). Yet the above examples (which are just a few of a wider range of examples of creative subtitles and motion typography) prove that it is possible for subtitles to become more than just a "blemish on the film screen". Perhaps, then, it is time for AVT academics to take a leaf out of the filmmaker's book, rather than lay back and accept the shortcomings of their practice. It is for this reason that this article has stressed the importance of a multidisciplinary creative subtitling practice and, now that we have observed the potential of such an approach, we may begin to introduce film studies principles to the suggested creative subtitling practice.

Firstly, it is worth considering the way in which film titles are used to convey meaning. The advances in motion graphics software in recent years have led to increased interest in both the theory and practice of title design. Yet, as in the case of intertitles, the creative design of main titles, which usually 
include the film's title and opening credits, is no new idea. Dick (2005: 23) has detailed several examples of such credits, including those used in Preston Sturges's The Lady Eve (1941), which features the film title slithering across the screen in the form of a snake, and those used in Hitchcock's Psycho (1960). Dick (2005: 23) describes how the credits used in Psycho "intersect, coming onto the screen horizontally and vertically as the actors' first and last names split apart". These credits are used, therefore, not just as an aesthetic tool, but as a means of preparing the audience for the themes and plotlines they are about to witness (in the case of Psycho, themes of split personalities and slashing). If opening credits can become representative of a film text, it then stands to reason that subtitles, when designed creatively, can also become representative of the narrative and the mise en scène in each specific film, and even in each specific scene.

We have already seen the ways in which creative subtitles may interact with the mise en scène through their use of different positions, styles and colours. Yet the mise en scène is just one of the ways in which films construct meaning. What about the development of characters and the relationships between characters? While the subtitles in Slumdog Millionaire are positioned to show the flow of dialogue between characters, the position of subtitles could also be used to highlight the relationships between characters, for example, between two lovers, or behind the back of a character who is hiding a secret. The choice of font could be used to become denotative of that particular character, with different font types being used for different characters. Even colours, where appropriate, could be used to represent a specific character. Likewise, subtle effects could be added to indicate the emotional or physical state of a particular character: for example, text with low opacity for a character who is weak or tired. In a creative subtitling strategy, all sorts of techniques can be applied to expand upon the subtitles' communicative functions. Yet perhaps some more specific 'rules' can be applied if we consider the norms that surround the art of filmmaking and, in particular, the rules of film editing. The Functionalists argued that editing was the one technique unique to filmmaking that could position it as an art form. Perhaps the rules of film editing can therefore develop our subtitling practices in the same way.

Multi Academy Award winning film editor and sound designer Walter Murch, whose projects include Apocalypse Now (Coppola, 1979), The Godfather: Part III (Coppola, 1990) and The English Patient (Minghella, 1996), has recommended six criteria to be considered in the film editing process. In his book, In the Blink of an Eye: a Perspective on Film Editing (2001), Murch puts forward a "Rule of Six" which prioritises emotion (51\%), story (23\%), rhythm 
$(10 \%)$, eye-trace $(7 \%)$, planarity $(5 \%)$ and the three-dimensional space of action (4\%) (ibid: 18). Murch is quick to point out that this is not a binding set of rules and is also aware that it may be impossible to fulfil all of these criteria. It is for this reason that he allocates each criterion a percentage of importance: a ranking that is very telling about what is considered important in the cinema. The two lowest ranking criteria, for instance, are arguably the most technically based criteria, yet they amount to only nine percent of the total. Murch explains "planarity" as "the grammar of three dimensions transposed by photography to two (the dimensions of stage-line, etc)" and describes the "three-dimensional continuity of the actual space" as "where people are in the room and in relation to one another" (ibid.). These two criteria are usually seen as the key to continuity editing, as they create a 'real' three-dimensional space out of two-dimensional images, thus providing the viewer's sense of perspective and orientation. Interestingly, Murch suggests that the viewer's emotional response to a film is of much greater importance than their sense of perspective, or the technical constraints of the filmic medium. Emotion, it would seem, is even much more important than comprehension, at least on a visual level. Indeed, its allocated importance of fifty-one percent shows just how important it is for the film editor to "recreate the emotion of the moment" (ibid.). Not to be overlooked, the second criterion of story, while only half as important as emotion, represents an important factor in carrying the viewer along with the film's narrative. Finally, the third and fourth criteria of rhythm and eye-trace (the way in which the viewer's eye follows the on-screen action), although surprisingly low down on this recommended list, are still seen to be of greater significance than the often hailed technical rules such as the 180-degree rule and the 30-degree rule.

Having examined these six criteria, how can we now relate them to the development of a creative subtitling practice? Firstly, as in the film editing process, we may say that creative subtitles should respond to the emotion of the moment (implying that they may change throughout the film, depending on events, characters and settings). Engaging with the emotion of the moment in subtitles can take both linguistic and graphic forms. Linguistically, the subtitler's translation strategy may vary according to the character who is speaking (for example, with different registers, vocabulary and colloquialisms), according to the relationship between characters and according to the situation in which they find themselves. Graphically, creative subtitles may mirror the emotion of the moment by integrating into the mise en scène in terms of the colours, styles or special effects used. With regard to advancing the story, subtitles obviously play an important role through their translation 
of dialogue, on-screen signs and other written materials, and even the translation of songs. Their legibility is therefore of a certain significance to the film's narrative, and care must be taken to ensure their (linguistic and visual) readability and their on-screen duration. Rhythmically, it would seem important that subtitles follow the rhythm of the film text, mirroring the rushed, unstable effect of fast shot changes or the measured, relaxed effect of slow shot changes. A careful balance must be drawn between film rhythm and the duration of subtitles, which is not easy to achieve. Following this ranked system, however, it would follow that the story or narrative, and therefore legibility, is of greater importance than rhythm and therefore takes priority. Murch's criterion of "eye-trace" is also significant when considering a creative subtitling practice, as it seems to pose an argument for subtitles being raised into the heart of the on-screen action. In so doing, the viewer would arguably remain engaged with the on-screen action, although this theory would need to be corroborated by further research. We are now left with the final two criteria, which relate to the technical rules normally imposed on film editing. When considering the development of a creative subtitling practice, this then leaves us with the rules normally imposed on standard subtitling practice. These conventions, while they must be considered, are perhaps not as steadfast as they may seem and, when considered alongside other criteria, fall short of singlehandedly producing an adequate emotional engagement or narrative function.

This discussion has largely developed a creative subtitling strategy as a response to the visual elements of the film text. Yet the film text is not just a visual text; it is an audiovisual text, and therefore its acoustic channel cannot be ignored. Once, again, when considering a creative approach to subtitle production, we may turn to the early design of intertitles and their rendering of the acoustic track. Bordwell, Staiger and Thompson (1985: 188) have described some of the early methods used by silent era directors and intertitle writers to graphically represent the characters' spoken dialogue. These include the use of different sizes of typeface to designate the volume of the character's voice (with small letters for whispers and large letters for shouts), and the use of words with letters out of line to represent the dialogue of a drunken man. In particular, Bordwell, Staiger and Thompson cite Emmett Campbell Hall, the director of Road o' Strife (1915), who attempted to prevent his intertitles from interrupting the onscreen action: 
Some dissolve in and out, others appear abruptly and slowly fade, still others merely flash on and instantly disappear, as a sharp, explosive "No!" seems to do. We have undertaken to visually approximate sound effects. (Hall 1915; quoted in Bordwell, Staiger \& Thompson 1985: 188)

These techniques, although almost a century old, seem to have been lost in the commoditisation of film production and the standardisation of subtitling norms. Yet they propose interesting methods for dealing with film sound. Yet further techniques for responding to music, and in particular songs, in film can be seen in the original release of Willy Wonka \& the Chocolate Factory (Stuart, 1971) (see Figure 4). In two songs sung by the Oompa Loompas, some of the words appear onscreen as they are sung, synchronised with the music's rhythm. In the first instance, the words appear alongside a split screen in different colours depending on the singer, while in the second example key lyrics appear on a computer screen, thereby integrating with the mise en scène.

The examples provided here are indicative of just some of the techniques at the creative subtitler's disposal for the creative rendering of a film's audio track. Other techniques may be developed if we consider the various uses of sound in the audiovisual text, including natural sound, sound perspective, voice-over narration and music. Natural sound is a term that covers all sound emanating from a visible onscreen source, including dialogue. In order to graphically represent the aural characteristics of the spoken dialogue, the
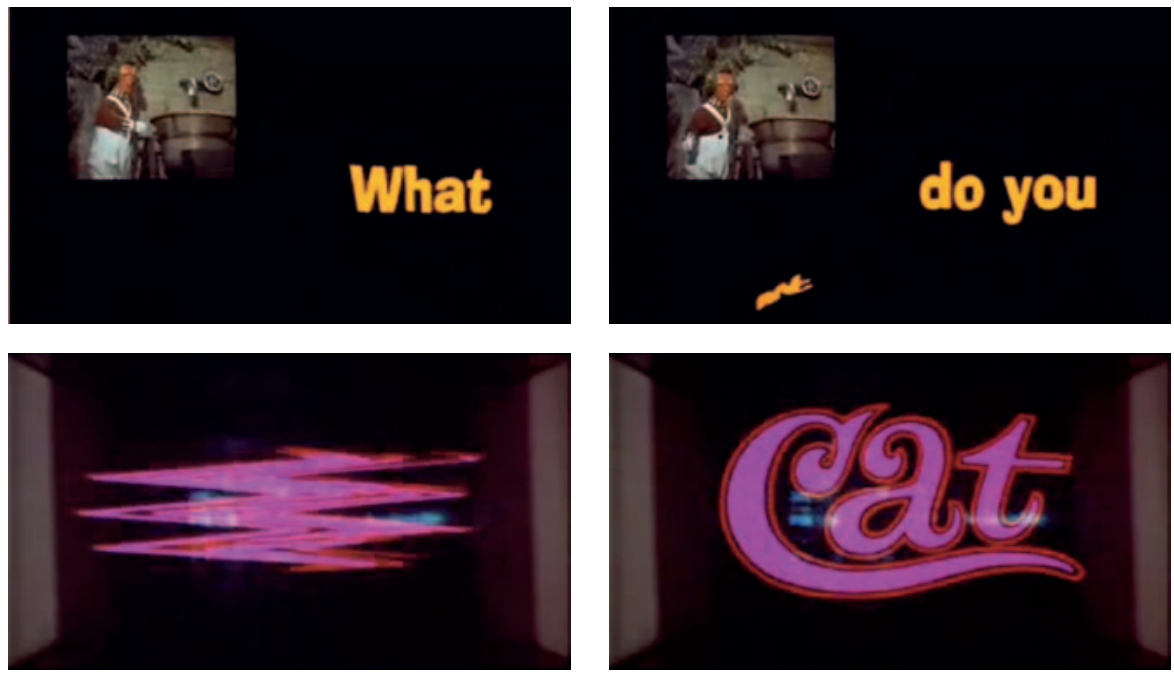

Figure 4: Titled songs in Willy Wonka \& the Chocolate Factory. 
creative subtitler may use capital letters or larger text for shouted words, and smaller or slightly transparent text for whispers. If a character is weak or tired and this is represented through their voice, the text may appear transparent, wispy or appear to float. The positioning of the subtitles may also vary according to the onscreen position of the speaker: in this way, the text may appear to come from its corresponding aural source. Similarly, subtitle text may vary with the aural perspective, that is, the impression of distance that is created through sound. Just as the subtitle position may vary along with the position of the speaker, the text may appear larger or smaller depending on how close the character is to the camera (if, that is, the volume of their voice also changes). Currently, voice-over narration is usually subtitled with italic text. Yet perhaps, in a creative subtitling practice, this form of narration could be attributed a specific colour, typeface or position (according to the requirements of the individual film) to set it apart from the natural dialogue of the characters. These are, of course, just some possible suggestions for creatively responding to sound in film texts. Further research into the theory and practice of film sound must still be carried out in order to fully respond to the cinema's varying soundscapes. Furthermore, while this work has come some way to developing a multidisciplinary approach to creative subtitling, yet more research remains to be carried out into the insights to be gained from the disciplines of graphic design and, in particular, motion graphics.

\section{The Evolving Role of the Creative Subtitler}

While it may be argued that these recommendations are overly vague and nonspecific, I would argue that, to achieve a truly creative subtitling practice, it is useless to attempt to build yet another lengthy set of overly restrictive, specific norms. It has been stated that a creative subtitling practice must evolve and adapt according to the film to be subtitled. How, then, could an overly prescriptive set of subtitling norms ever create a fully flexible, creative approach? The aim of this research, therefore, is not simply to impose a new uniform theory of subtitling, but to propose subtitling as contingent upon the film text: as a creative response to individual qualities within and between films. It has also been argued that a truly creative subtitling practice must adopt a multidisciplinary approach, drawing upon concepts from film studies, and perhaps even from graphic design, to facilitate the subtitler's understanding of the semiotic codes used within the film text and the design techniques that these require. The need for this multidisciplinary understanding has been demonstrated in the four existing examples of creative subtitles included in this paper, which have originated with the filmmakers rather than 
film subtitlers. This multidisciplinary approach requires, in turn, that the creative subtitler has a very specialised skill set, thus evolving the subtitler's current role. This expanded skill set means that the subtitler must possess, not only the skills of a translator (with all the linguistic capabilities and cultural awareness that this entails), but also the skills of a cineliterate film viewer, capable of reading the film text, its characters and their relationships, and the various filmic devices used to convey meaning.

In addition to this expanded skill set, a creative subtitling practice may require the use of film editing software rather than industry standard subtitling software in order to gain further control over the colours, styles, positions and effects that may be achieved. These two new requirements together imply a great change in the role of the subtitler. As opposed to their current role as translator, the creative subtitler becomes something of a translatortitle designer, capable of producing subtitles that are linguistically and aesthetically pleasing. It therefore follows that the translator-title designer, rather than remaining outside of the filmmaking process, should become part of the postproduction team, working alongside the film editors and title designers. This would enable the translator-title designer to gain closer working access to the film's production team, including the director, and consequently achieve greater insights into the film's style and the director's intentions. In turn, this would facilitate a creative subtitling that truly responds to the film and, moreover, becomes an aesthetic extension of the film itself.

Is this evolved role of the subtitler idealistic? Perhaps. Is it too much to ask for subtitling to become part of the filmmaking process? Perhaps. Yet it would seem that certain filmmakers are already moving in this direction. The box office success and critical acclaim achieved by Slumdog Millionaire demonstrate that creative subtitles can prove very successful when used in multilingual sequences in films. The film's success among the public certainly suggests that creative subtitles are of greater appeal to a more mainstream audience. Clearly, however, the cost of producing such subtitles is a factor that cannot be ignored in the filmmaking business. Each specific, tailored decision regarding the colour or position of a single subtitle will cost more than the automatic styling provided by standard subtitling software. This difference in cost is, perhaps, the reason why even existing films that have used creative subtitling have not used it throughout the whole film. The creative subtitling used in Night Watch, for example, is far from consistent, with many subtitles returning to standard format. Furthermore, in its home entertainment release, this creative subtitling track is only included as a special feature on the special edition DVD release, thereby saving costs by ensuring that the 
standard release is easy to translate into different languages. Nevertheless, the increasing number of creatively subtitled films and their relative success among the public may prove reason enough for some filmmakers, who have both the budget and the creative vision to experiment further with such creative subtitling techniques.

In spite of these issues of time and cost, it is clear that new digital technologies are advancing and evolving the way in which films are made. Subtitling practices, conversely, have remained relatively unchanged throughout their history. The recent turn towards creative subtitling, not to mention the rise in fansubbing practices, proves that subtitling must begin to advance along with these new digital technologies. Subtitling can no longer afford to remain the same practice it was fifty years ago, nor can professional subtitlers and academics in audiovisual translation continue to settle for the inadequacy of their field. Subtitles can be more than simply a "blemish" on the screen. Indeed, in addition to their visually aesthetic qualities, they can add greater levels of linguistic, pragmatic and cultural understanding that may enhance the viewer's film experience and also lead them to an "experience of translation" (Nornes 1999: 18).

\section{Conclusion}

In this paper I have attempted to highlight the need for a multidisciplinary approach within audiovisual translation and, in particular, within the creative subtitling practice. We have examined the historic origins and aesthetic precedents for the present turn towards creative subtitling along with the recent practical turn in theatre translation, which has recognised the need for a practical, collaborative approach between translators, theatre directors and actors. Following Johnston's argument, it would seem that film translation also has more to do with film practice than translation theory, which leads us to the need for multidisciplinary research between film studies and audiovisual translation. Initial examples of such work have already been carried out by academics such as Nornes $(1999,2007)$ and Chaume $(2004)$. On the basis of this existing research, I have attempted to put forward a multidisciplinary approach to the practice of creative subtitling. This approach draws upon the aesthetic qualities of existing creative subtitles in film texts along with principles from film studies, including the composition of the mise en scène, characterisation and film editing principles. On the basis of these theories, it has been possible to develop recommendations (not norms, rules or conventions) for the development of a creative subtitling practice, including the use of varying colours, typefaces, styles, special effects and positions. Finally, I have 
explained how this creative practice may alter the role of the translator within the filmmaking and postproduction processes, along with the problems that may face the creative subtitling practice in terms of its related production times and costs.

This paper has strived to develop the graphic qualities of a creative subtitling practice and therefore less attention has been paid to the linguistic aspects of such a practice. Further research may look with greater detail into Nornes' recommendations for linguistically "abusive" subtitling practices $(1999,2004)$ and the more general ethical and philosophical arguments within translation theory, including Lewis' theory of "abusive fidelity" (1985), Pound's notion of experimentalism (1929) and Bhabha's concept of the "third space" (1994). As stated earlier in this paper, a truly multidisciplinary approach to creative subtitling requires further research into other related disciplines including graphic design and, in particular, motion graphics and the design of film titles. Furthermore, having developed the practice of creative subtitling, it will soon prove necessary to test the reception of such subtitles, through methods such as questionnaires and eye-tracking software, in order to learn the ways in which they are viewed and the cognitive and affective responses that can be achieved. The large amount of research that remains to be carried out in response to the creative subtitling practice demonstrates that this is a topic that has far to go within the field of audiovisual translation. Furthermore, the increasing number of films using creative subtitling techniques indicates that this is a practice that will continue to grow with new digital technologies and increased public approval. The creative subtitling practice therefore poses exciting new directions for the multidisciplinary theory and practice of audiovisual translation.

\section{References}

BHABHA, Homi. (1994) The Location of Culture. London \& New York: Routledge. Bordwell, David; Janet Staiger \& Kristin Thompson (eds.) (1985) The Classical Hollywood Cinema: Film Style and Mode of Production to 1960. London: Routledge.

CAFFREY, Colm. (2009) Relevant abuse? Investigating the effects of an abusive subtitling procedure on the perception of TV anime using eye tracker and questionnaire. PhD thesis, Dublin City University.

Chaume Varela, Frederic. (2004) Cine y traducción. Madrid: Cátedra.

Chaume Varela, Frederic. (2004) "Film Studies and Translation Studies: Two Disciplines at Stake in Audiovisual Translation." Meta 49:1. pp. 12-24. 
Díaz CinTAS, Jorge. (2005) "Back to the Future in Subtitling." MuTra Conference Proceedings 17. Full-text version at: <http://www.euroconferences.info/proceedings/2005_Proceedings/2005_proceedings.html> [Accessed $7^{\text {th }}$ November 2011].

DíAz CinTAS, Jorge \& Aline Remael. (2007) Audiovisual Translation: Subtitling. Manchester: St. Jerome Publishing.

Dick, Bernard F. (2005) Anatomy of Film. Boston \& New York: Bedford/St. Martin's. 5th edition.

FERRER SimÓ, María Rosario. (2005) "Fansubs y scanlations: la influencia del aficionado en los criterios profesionales." Puentes 6. pp. 27-43.

FOERSTER, Anna. (2010) "Towards a creative approach in subtitling: a case study." In: Díaz Cintas, Jorge; Anna Matamala \& Josélia Neves (eds.) 2010. New Insights into Audiovisual Translation and Media Accessibility. Media for All 2. Amsterdam: Rodopi. pp. 81-98.

HaLl, Emmett Campbell. (1915) "Unique Captions in Road O’Strife." Motography 13:13. p. 470.

HARRIS, Genevieve. (1916) "The Aryan." Motography 15:14. p. 766.

IVARSSON, Jan \& Mary Carroll. (1998) Subtitling. Simrishamn: Transedit.

Johnston, David. (2010) "Metaphor and Metonymy: the Translator-Practitioner's Visibility." In: Baines, Roger; Cristina Marinetti \& Manuela Perteghella (eds.) 2010. Staging and Performing Translation: Text and Theatre Practice. London: Palgrave Macmillan. pp 11-30.

Karamitroglou, Fotios. (1998) "A proposed set of subtitling standards in Europe." Translation Journal 2:2. Full-text version at: <http://accurapid.com/ journal/04stndrd.htm $>$ [Accessed $7^{\text {th }}$ November 2011].

LEWIS, Philip. (1985) "The measure of translation effects." In: Venuti, Lawrence (ed.) 2004. The Translation Studies Reader. London \& New York: Routledge. 2nd edition. pp. 256-275.

Mayoral AsEnsio, Roberto; Dorothy Kelly \& Natividad Gallardo. (1988) "The concept of constrained translation: non-linguistic perspectives of translation." Meta 33:3. pp. 356-67.

MurCH, Walter. (2001) In the Blink of an Eye: a Perspective on Film Editing. Los Angeles: Silman-James Press.

Nornes, Abé Mark. (1999) "For an Abusive Subtitling." Film Quarterly 52:3. pp. 17-34.

Nornes, Abé Mark. (2007) Cinema Babel. Minneapolis: University of Minnesota Press.

Pound, Ezra. (1929) “Guido's relations." In: Venuti, Lawrence (ed.) 2004. The Translation Studies Reader. London \& New York: Routledge. 2nd edition. pp. 86-93. 
TITFORD, Christopher. (1982) "Sub-titling: constrained translation." Lebende Sprachen 27:3. pp. 113-116.

\section{Audiovisual Materials}

Bekmambetov, Timur. (2004) Night Watch - Nochnoy dozor. Russia.

Boyle, Danny. (2008) Slumdog Millionaire. UK.

Onuma, Shin. (2007) Paniponi Dash! Lethal Lesson. Japan.

Roach, Jay. (2002) Austin Powers in Goldmember. USA.

Sapir, Esteban. (2007) La antena. Argentina.

Stuart, Mel. (1971) Willy Wonka \& the Chocolate Factory. USA.

\section{BIONOTE / NOTA BIOGRÁFICA}

\section{Rebecca McClarty}

Rebecca McClarty is currently undertaking a PhD at Queen's University Belfast. Her practice-based thesis, entitled Film and Translation: the Art of Subtitling, draws on concepts from both Translation and Film Studies to suggest a new turn in film subtitling towards a stylised, creative form of translation that responds to the particular characteristics of a given film text. Rebecca has a BA in French and Spanish (QUB 2008) and an MA in Translation (QUB 2009).

Rebecca McClarty es una estudiante de doctorado en Queen's University Belfast. Su tesis, que se titula Cine y traducción: el arte de la subtitulación, se basa en conceptos tanto de los estudios de traducción como de los estudios cinematográficos. En su investigación, Rebecca pretende sugerir un nuevo giro en el subtitulado cinematográfico hacia una forma de traducción estilizada y creativa que responde a los rasgos particulares de una determinada película. Rebecca es licenciada en francés y español (QUB 2008) y tiene un Máster en Traducción (QUB 2009). 